\title{
Organizational Leadership and Collective Action in International Governance: An Introduction
}

\author{
Aseem Prakash \\ University of Washington \\ Adrienne Héritier \\ European University Institute \\ Barbara Koremenos \\ University of Michigan \\ Eric Brousseau \\ Paris-Dauphine University
}

This symposium grew out of a workshop organized by the European University Institute, Florence in 2013. The main motivation of this endeavour is to think systematically about the role of agency in global governance within the collective action perspective. Collective action is at the core of governance and policy studies (Ostrom, 1998). Institutions, as rules of behaviour facilitating and restricting actors' interactions, influence the initiation, the sustenance and the success of collective action (North, 1990). However, the structural bent in the institutionalist research program has not adequately addressed, and sometimes even ignored, the role of leaders in the emergence, working and efficacy of institutions.

Leadership can be exercised by individuals as well as organizations. This symposium focuses on political leadership exercised by organizational actors - state, international organization and private authority organization - and how this political leadership mitigates collective action problems and thereby shapes governance outcomes.

Leaders can be viewed as political entrepreneurs who bring together actors with different preferences and interests with the objective to facilitate the collective pursuit of a common agenda (Schelling, Schneider and Teske, 1992; Moravcsik and Katzenstein, 1998; Hix and Høyland, 1999). The other actors participating in collective action might pay heed to leaders because leaders can supply positive or negative incentives (Burns, 1987). Sometimes, actors placed in specific organizational roles emerge as leaders because, unlike their predecessors, they are willing to exercise the power and authority that the organizational position vests in them. Leaders need not always have dramatic persona and lead the charge sitting on a beautiful stallion! They can be humdrum, routine actors that seek to deploy available resources in creative ways to facilitate collective tasks.

Our focus is on the role of organizational actors (and sometimes individuals in these organizations) in resolving collective action problems. Much of the literature attributes collective action problems to either structural attributes of the problem (the nature of the game such as cooperation or coordination problems) or the preferences/attributes of the actors involved (such as the distribution of benefits and costs). The role of specific organizational actors in resolving collective action issues remains underexplored (hegemonic stability theory being a notable exception). This symposium explores how specific organizational actors work within these structural constraints within a specific institutional context and change either the nature of the game or the calculus of actors facing this game - that is, exert leadership.

We focus on how organizational actors, state and nonstate, might exercise leadership at the regional and/or global level in the context of specific problem structures, macro-economic conditions and decision making rules. Further, these papers examine how their effectiveness is shaped by resources at their command and the strategies 
they are able to employ to persuade, incentivize, or coerce actors towards a particular solution.

In particular, this symposium highlights how strategic interactions shape the exercise of leadership, i.e. how actors with specific preferences over outcomes strategically interact with other actors with different preferences in varying institutional contexts. These interactions are examined in the context of different types of collective action problems, some involving distributive or redistributive issues while others focus on problems of coordination and enforcement. Importantly, they emphasize the importance of a variety of resources that may be used in exercising leadership: material, positional/formal authority, informational and ideational. Leaders may employ merely transactional skills (in which the distribution of power among the involved actors is not altered) or they may use transformational skills (in which underlying actors' capabilities, resources, and/or preferences for specific outcomes are altered). The substantive policy problems central to the analysis are financial markets regulation, environmental regulation, health and safety regulation, technical norms, human rights norms and foreign and security policy. Finally, the papers examine cases of both the successful and less successful exercise of leadership.

The article by Barbara Koremenos, 'The Role of State Leadership in the Incidence of International Governance,' explores the role of leadership in the incidence of international governance structures. The article focuses on state leadership. The basic theoretical premise is that the cooperation problem(s) underlying the cooperative endeavour (or put differently, the underlying strategic structure which reflects the joint and conflicting interests of state parties) are key to understanding the necessity of leadership with respect to the incidence of international cooperation, that is, agenda setting by putting forth the first draft of an international agreement addressing the issue at hand and remaining in control of subsequent drafts. The paper thus explores whether and how much we can explain regarding the role and nature of leadership in international cooperative endeavours with a very simple focus on state interests and state power. The theory is brought to life with cases from both the security and human rights policy making realm. The paper argues that powerful states do not unconditionally take leadership roles in setting the agenda for the negotiation of international agreements; they do so only when their interests cannot be served without leadership.

The article by Adrienne Héritier and Aseem Prakash, 'A Resource-based View of the EU's Regional and International Leadership,' examines variations in the EU's success to enact and enforce policies that lead to the supply of regional or global public goods. It examines the organizational leadership of the EU and explores how it deploys its positional resource to enact laws with the objective to supply public goods. Actors resist contributing to public good provision if they view themselves as net losers in the bargain. Leaders wading into regulatory politics need to assess the appropriateness of their resource base in relation to their policy ambitions and skilfully deploy these resources. Otherwise, they will not be able to prevail over the 'losers' resisting the regulatory initiative. Empirically, the paper looks at two issue areas: financial markets and environment. The financial market cases pertain to the EU's quest to provide regional public goods, while the environmental cases pertain to the EU's quest to provide regional as well as global public goods by leveraging its authority to regulate access to EU markets to nonEU firms. These cases reflect instances of leadership success as well as failure. In the financial market cases, the paper examines the Outright Monetary Transactions (success) and the Banking Union's Single Resolution Mechanism/Pan European Deposit Insurance (less successful) while the environmental cases pertain to chemical regulation (success) and airline emissions (failure). These cases reveal the EU's skill and limitations in deploying its positional authority to induce contributions from EU member governments, EU firms and nonEU firms to public good provision.

The article by Magnus Schoeller, 'Explaining Political Leadership: Germany's Role in Shaping the Fiscal Compact,' explores why and how political leaders emerge, and, once in charge, how these leaders influence outcomes. The paper proposes a theory of political leadership which takes into account both the structural and the behavioural aspects of this concept. It suggests that a leader emerges if there is a supply of and demand for leadership. While the supply depends on a leader's expected benefits, the demand is determined by the followers' status quo costs. The second step concerns a leader's impact. Political leaders influence outcomes by translating their power resources into strategies. In addition to their command over resources, the leadership success is also influenced by the heterogeneity of preferences of their followers, and the adaptability of the institutions to be changed. The paper applied this theory to understand the role of Germany in the European Fiscal Compact. It examines why Germany was able to emerge as a strong leader in autumn 2011. While economic resources facilitated Germany to influence the realization of the Fiscal Compact, its leadership efforts were aided by homogeneity of preferences of member states' and the low adaptability of the relevant institutions.

The fourth paper by Walter Mattli and Jack Seddon, 'New Organizational Leadership: NonState Actors in Global Economic Governance,' questions the state-centred account of global leadership. While recognizing that inter-governmental organizations (IGOs) supply leadership in many venues of global governance given their 
regulatory competence, operational capacity and legitimacy to tackle cooperation challenges, sometimes they lack the technical expertise and resources to address complex cooperation challenges. Recognizing their limitations, IGOs - frequently with state support - have co-opted specific nonstate actors to help achieve their goals. This study considers the distributional implications of co-optation. It describes and explains why some types of co-optation have led to a transfer or sharing of authority and organizational leadership while other types leave the status quo intact. The study concludes that leadership in global governance is rapidly becoming more diffuse in key economic areas.

Finally, the article by Angel Saz-Carranza, 'Agents as Broker: Leadership in Multilateral Organizations,' explores leadership in multilateral contexts. Using principal-agent theory, the paper suggests that IGO leaders succeed when they recognize that they act on behalf of specific principals, and they must devise solutions that are acceptable to the winning coalition of these principals. Yet, contrary to the principal-agent approach, leaders do not manipulate information problems by substituting their preference for those of their principals. Further, principals do not always know their preferences, or their ordering. Thus, agents need to provoke principals' preferences with the objective of helping them to articulate or order these preferences. They seek to act as policy brokers and construct a solution which is acceptable to most. Yet, in this construction, they can sometimes smuggle in their own preferences - but eventually, IGO leaders recognize the limits of their power. The paper examines two cases of successful leadership: NATO Secretary General's work during the organization's enlargement process to the east during the late 1990s, and the EU High Representative's work in institutionally creating the EU's Common Foreign and Security Policy during the first decade of 2000.

In conclusion, this symposium seeks to make four contributions to the study of leadership in global governance. First, while describing different approaches to leadership, it grounds itself in rational choice institutionalism. In doing so, instead of invoking the role of charisma or personality traits, it focuses on resources and strategies actors in leadership roles deploy in specific problem contexts. Second, we view leadership processes as a problem solving exercise; specifically, solving collective action problems across multiple but nested arenas. Third, the papers recognize the important role of power - the ability to alter payoffs associated with different strategies available to 'followers', as well as to change the strategies available to them in the exercise of leadership. Yet, they also recognize that leaders often need to stitch together a coalition to solve a problem. To do so, leaders may not be able to rely on power alone; noncoercive strategies which involve persuasion are required as well. Finally, while the exercise of leadership by states is critical in the study of regional and global governance, scholars must pay close attention to the role of nonstate actors and networks as well.

\section{References}

Burns, J. M. (1978) Leadership. New York, NY: Harper Torchbooks.

Hix, S. and Høyland, B. (1999) The Political System of the EU. London: Macmillan.

Moravcsik, A. and Katzenstein, P. J. (1998) The Choice for Europe. Ithaca, NY: Cornell University Press.

North, D. C. (1990) Institutions, Institutional Change and Economic Performance. New York, NY: Cambridge University Press.

Ostrom, E. (1998) 'A Behavioral Approach to the Rational Choice Theory of Collective Action', American Political Science Review, 92, $1-22$.

Schneider, M. and Teske, P. (1992) 'Toward a Theory of the Political Entrepreneur: Evidence from Local Government', American Political Science Review, 86 (.03), pp. 737-747.

\section{Author Information}

Aseem Prakash is Professor of Political Science, the Walker Family Professor for the College of Arts and Sciences, and the Director of the Center for Environmental Politics at University of Washington, Seattle. He is the General Editor of the Cambridge University Press Series in Business and Public Policy. He serves as the Vice President of the International Studies Association for 2015-2016.

Adrienne Héritier is professor emeritus for political science at the political and social sciences department at the European University Institute in Florence. She has conducted research on changing rules of decision-making in the EU, Europeanisation and comparative public policy analysis in the EU, regulation, new modes of governance and the self-regulation of industry in the shadow of hierarchy.

Barbara Koremenos, Associate Professor of Political Science at the University of Michigan, received her PhD from the University of Chicago. She won a National Science Foundation CAREER Award for her interdisciplinary research on international relations and law. Her book, The Continent of International Law, is forthcoming with Cambridge University Press.

Eric Brousseau is Professor of Economics and Management at the University Paris-Dauphine. He is a member of Dauphine Research in Management, a Joint Research Center between Dauphine and the CNRS. He is the founder and the director of the European School for New-Institutional Economics, and is a Past-President of the International Society for New-Institutional Economics. 